\title{
Calcium oxychloride formation in pastes containing supplementary cementitious materials: Thoughts on the role of cement and supple- mentary cementitious materials reactivity
}

\author{
Prannoy Suraneni ${ }^{\mathrm{a}}$, V. Jafari Azad ${ }^{\mathrm{a}}$, O. Burkan Isgor ${ }^{\mathrm{a}}$, W. Jason Weiss ${ }^{\mathrm{a}^{*}}$ \\ ${ }^{a}$ Department of Civil and Construction Engineering, Oregon State University, Corvallis, OR - 97331, USA \\ Received: 05 May 2016 / Accepted: 14 May 2016 / Published online: 29 May 2016 \\ (C) The Author(s) 2016. This article is published with open access.
}

\begin{abstract}
Over the last decade many concrete pavements in North America have begun to show excessive damage at the joints. This damage appears to be due to two primary causes: classic freeze-thaw damage due to local saturation caused by the pooling of water at the joints, and formation of an expansive phase known as calcium oxychloride due to a reaction between chloride-based deicing salts and calcium hydroxide in concrete. This letter explores the formation of calcium oxychloride in cementitious matrices based on constituent materials and mixture compositions. Low temperature differential scanning calorimetry and thermogravimetric analysis were used to quantify the amount of calcium oxychloride and calcium hydroxide, respectively. Thermodynamic modeling was used to predict calcium hydroxide contents from the constituent material compositions. It is shown that calcium oxychloride contents are well correlated with calcium hydroxide contents in cementitious pastes. Supplementary cementitious materials, such as fly ash and slag, can reduce calcium oxychloride formation by reducing the amount of calcium hydroxide. Complexities in the determination of reactivity of supplementary cementitious materials based on their replacement level and different water-to-cement ratios are discussed. Although it is clear that supplementary cementitious materials are beneficial in reducing calcium oxychloride formation, additional analysis tools are needed to more accurately quantify the specific mechanisms (such as dilution, pozzolanic or hydraulic reaction, and changes in cement hydration) that result in the beneficial aspects of each supplementary cementitious material.
\end{abstract}

Keywords: Deicing salts; Calcium oxychloride; Differential scanning calorimetry; Thermogravimetric analysis; Thermodynamic analysis

\section{Introduction}

Deicing salts are used throughout cold regions in North America to melt ice that forms on the surface of concrete pavements. These salts are typically chloride-based in the form of sodium chloride, calcium chloride, magnesium chloride, or their combinations [1]. The use of chloride-based deicing salts is already well known to potentially result in several durability issues in concrete such as salt scaling damage [2, 3] and reinforcement corrosion [4, 5]. In addition, chloride-based deicing salts may also interact chemically with concrete. This reaction can occur with the hydrated aluminate phases to form Friedel's or Kuzel's salts $[6,7]$ and with calcium hydroxide $\left(\mathrm{Ca}(\mathrm{OH})_{2}\right.$ or $\left.\mathrm{CH}\right)[8,9]$ to produce an expansive salt known as calcium oxychloride (CAOXY). Historically, the formation of CAOXY has not received much attention; however, recent research [10-12] has suggested that CAOXY formation can cause substantial damage in concrete, particularly along pavement joints where deicing salt concentrations can be rather high. CAOXY formation occurs at temperatures above freezing, and phase isopleths have been developed to illustrate the temperatureconcentration relationships [13-15].
CAOXY formation occurs primarily due to the reaction of $\mathrm{CH}$ with calcium chloride $\left(\mathrm{CaCl}_{2}\right)$ [13] or magnesium chloride $\left(\mathrm{MgCl}_{2}\right)$ [14]. Relatively small amounts of CAOXY formation have been observed with sodium chloride $(\mathrm{NaCl})$ [15].

While several forms of CAOXY are known to form at different temperature and relative humidity (RH) values [16], Eq. (1) is believed to show the common type of CAOXY, known as the 3:1:12 form:

$\mathrm{CaCl}_{2}+3 \mathrm{Ca}(\mathrm{OH})_{2}+12 \mathrm{H}_{2} \mathrm{O} \rightarrow 3 \mathrm{Ca}(\mathrm{OH})_{2} \cdot \mathrm{CaCl}_{2} \cdot 12 \mathrm{H}_{2} \mathrm{O}$

CAOXY is expansive; hence, its formation can lead to damage when it occurs in a cementitious matrix [13]. This form of damage is believed to be increasingly observed across North America; it occurs within the first decade of service, and is unsightly, and difficult and expensive to repair [10-12, 17, 18]. Several mitigation strategies have been proposed to reduce the amount of CAOXY including the use of supplementary cementitious materials (SCMs) [19-22], preferential carbonation [23], or topical treatments [20]. 


\section{Objective}

SCMs reduce $\mathrm{CH}$ in cementitious systems through a combination of dilution and pozzolanic reaction. This reduction in $\mathrm{CH}$ can be beneficial for concrete, especially for pavements, as it reduces the potential for CAOXY formation and damage in the field [19-22]. This letter discusses the role of water-to-cementitious materials ratio $(\mathrm{w} / \mathrm{cm})$, SCM type, and replacement level in the reduction in $\mathrm{CH}$ contents observed with SCMs and presents some thoughts on the degree of hydration of the cement and the degree of reactivity of the SCM. The second objective of this study is to show the relationship between $\mathrm{CH}$ and CAOXY contents; this is important in practice to develop mixture designs that show very low damage due to CAOXY formation.

\section{Materials}

Ordinary portland cement (henceforth, cement or plain cement), ground granulated blast furnace slag, and Class F fly ash were used in this study. The phase composition of the cement (a Type I OPC which contained $4 \%$ interground limestone) was $52 \%$ alite, $18 \%$ belite, $7 \%$ aluminate, and $10 \%$ ferrite, as provided by the manufacturer. Oxide compositions of these materials are provided in Table 1. Pastes with a w/cm of 0.36 and 0.50 were prepared using cement and cement with $20 \%, 40 \%$, and $60 \%$ volumetric replacements of slag or fly ash. Specific gravities for cement, slag, and fly ash were $3.15,2.9$, and 2.6 , respectively.

Pastes were prepared by mixing in a vacuum mixer at $400 \mathrm{rpm}$ for $3 \mathrm{~min}$, with a short break after $1.5 \mathrm{~min}$ to scrape material off the mixer and paddle. Samples were cast in cylindrical plastic molds $(38 \mathrm{~mm}$ diameter and $50 \mathrm{~mm}$ height) and sealed cured under ambient conditions (23 \pm $1{ }^{\circ} \mathrm{C}$ ) until testing (performed at $3,7,28$, and $49 \mathrm{~d}$ ). For each mixture, one sample was sealed and stored under ambient conditions for three days, and then cured at $50^{\circ} \mathrm{C}$ for $25 \mathrm{~d}$ to obtain aged samples. Based on maturity calculations, this accelerated curing is equivalent, in terms of the degree of hydration of cement, to $91 \mathrm{~d}$ curing under ambient conditions. After the samples were hydrated they were ground to a fine powder using a lathe grinder and passed through a $75 \mu \mathrm{m}$ sieve before testing. Testing was performed within one day of grinding.

Care was taken to minimize exposure to atmosphere in order to prevent carbonation; however, some carbonation cannot be avoided with the current set-up.

Table 1. Oxide compositions of cement, slag, and fly ash (in mass percent)

\begin{tabular}{cccc}
\hline & Cement & Slag & Fly ash \\
\hline $\mathrm{CaO}$ & 63.70 & 41.48 & 13.00 \\
$\mathrm{SiO}_{2}$ & 20.20 & 30.76 & 47.30 \\
$\mathrm{Al}_{2} \mathrm{O}_{3}$ & 4.70 & 13.08 & 16.50 \\
$\mathrm{Fe}_{2} \mathrm{O}_{3}$ & 3.30 & 0.77 & 6.10 \\
$\mathrm{MgO}$ & 0.70 & 4.50 & 5.30 \\
$\mathrm{SO}_{3}$ & 3.10 & 5.15 & 0.90 \\
$\mathrm{Na}_{2} \mathrm{O}_{\text {eq }}$ & 0.56 & 0.53 & 0.88 \\
\hline
\end{tabular}

\section{Methods}

Three techniques were used to study the amount of $\mathrm{CH}$ and potential for CAOXY formation: 1) thermogravimetric analysis (TGA) [21, 24], 2) low-temperature differential scanning calorimetry (LT-DSC), [19, 20, 25], and 3) thermodynamic modeling using the Gibbs Energy Minimization Software (GEMS) [26].

TGA was performed on the ground powder to determine $\mathrm{CH}$ contents. Approximately $30 \mathrm{mg}$ of ground powder was heated to $500{ }^{\circ} \mathrm{C}$ at a rate of $10{ }^{\circ} \mathrm{C} / \mathrm{min}$ under a nitrogen atmosphere. The amount of calcium hydroxide in the paste was estimated based on its mass loss during decomposition between $380{ }^{\circ} \mathrm{C}$ and $460{ }^{\circ} \mathrm{C}$. The tested samples of plain cement paste had a coefficient of variation of approximately $1 \%$ for TGA.

LT-DSC was performed on the ground powder to determine CAOXY contents by mixing $10 \pm 0.5 \mathrm{mg}$ of ground paste with $10 \pm 0.5 \mathrm{mg}$ of $20 \% \mathrm{CaCl}_{2}$ solution (by mass) to ensure a $1: 1$ mass ratio in a high-volume stainless steel pan. The pan was then sealed, placed in the LT-DSC and run through the following temperature cycle: isothermal at $25{ }^{\circ} \mathrm{C}$ for one hour; $3{ }^{\circ} \mathrm{C} / \mathrm{min}$ cooling until $-90^{\circ} \mathrm{C}$; low temperature loop from $-90{ }^{\circ} \mathrm{C}$ to $-70{ }^{\circ} \mathrm{C}$ and back to $-90{ }^{\circ} \mathrm{C}$ at $3{ }^{\circ} \mathrm{C} / \mathrm{min}$; $0.25^{\circ} \mathrm{C} / \mathrm{min}$ heating until $50^{\circ} \mathrm{C}$. As the mixture was heated, CAOXY melts (at around $30{ }^{\circ} \mathrm{C}$ under these conditions); the amount of CAOXY was found by normalizing the heat release on melting with that of pure CAOXY. Additional details of the LT-DSC testing are presented elsewhere $[20,25]$. The tested samples of plain cement paste had a coefficient of variation of approximately $5 \%$ for LT-DSC.

Thermodynamic modeling was used to estimate $\mathrm{CH}$ contents of tested pastes depending on cement degree of hydration (DoH) and SCM degree of reaction (DoR). These thermodynamic models were developed using GEMS software [26], which uses Gibbs Energy Minimization (GEM) method to analyze multiphase and multicomponent systems. Thermodynamic data for cement were obtained from a GEMS-formatted thermodynamic database [27-34]. The hydration of cement and the reactions of SCM in blended systems were modeled through dissolution of main oxides in the chemical system and precipitation of hydration/reaction products. The cement DoH and SCM DoR were treated separately. Assuming cement hydration and SCM reactions take place independently from each other initially, the hydration model developed by Parrot and Killoh $[32,34,35]$ was used to obtain the DoH of main cement phases (i.e., $C_{3} S, C_{2} S, C_{3} A$ and $C_{4} A F$ ). An assumption was made that the SCMs do not modify the cement DoH. However, it should be noted that SCMs may have strong effects on cement DoH, especially at early ages [36, 37]; these aspects will be discussed in later sections. For all SCM oxides, the DoR was assumed to be identical. Based on empirical evidence, hydrogarnet formation was limited in the blended systems up to $10 \%$ of its formation capacity as determined by thermodynamic analysis and experimental data from cement-only systems [34]. For each step of the 
thermodynamic analysis, the available water was obtained from calculating the amount of capillary water in the system based on the Powers and Brownyard model [38]. The hydration and SCM reactions were assumed to cease when the capillary water was consumed. The details of the numerical procedure of obtaining the capillary water from the total water is beyond the scope of this paper but can be found elsewhere [39]. Based on these assumptions, various DoR levels were analyzed for the SCMs.

\section{Results}

\subsection{Calcium Hydroxide (CH) content}

Fig. 1 and Fig. 2 show the $\mathrm{CH}$ contents as determined from TGA as a function of sample age for plain cement pastes and pastes where 20,40 , and $60 \%$ of the cement were replaced with fly ash or slag by volume, respectively. As the sample age increases, both cement DoH and SCM DoR increase. In the plain cements, the $\mathrm{CH}$ contents increase with sample age, because increased hydration results in the formation of more hydrated solids. The amount of $\mathrm{CH}$ in pastes with SCM is less than that in plain pastes due to a combination of dilution and the pozzolanic reaction. This is evident when $\mathrm{CH}$ reductions are considered; as an example, if the SCMs acted by dilution only, $\mathrm{CH}$ reductions would only describe approximately $70 \%$ of the observed reduction in $\mathrm{CH}$ for fly ash pastes with $\mathrm{w} / \mathrm{cm} 0.50$. The higher observed reductions are attributed to the pozzolanic reaction. As the volume of SCM increases, the total amount of $\mathrm{CH}$ decreases.

Fig. 1 and Fig. 2 show that the measured $\mathrm{CH}$ values with fly ash and slag are broadly similar at the same replacement levels, irrespective of the $w / \mathrm{cm}$. As the $w / \mathrm{cm}$ increases the measured $\mathrm{CH}$ values increase, both for plain cement pastes and with SCMs, possibly due to the availability of water, ensuring continuing hydration of cement [38]. At early ages, the amount of $\mathrm{CH}$ that forms is greater than that expected by dilution and this is likely due early age acceleration of cement hydration by SCMs due to their physical presence $[37,40]$. For example, for $\mathrm{w} / \mathrm{cm} 0.50$, at $7 \mathrm{~d}$, pastes with fly ash have around $10 \%$ higher $\mathrm{CH}$ than is expected when compared to plain pastes (assuming dilution and no other chemical effects). These calculations are approximate, since fly ash can significantly change cement DoH at early ages [36].

All tested experimental samples were modeled using GEMS to predict their $\mathrm{CH}$ contents [26] using $91 \mathrm{~d}$-equivalent curing ( $3 \mathrm{~d}$ at ambient temperature and $25 \mathrm{~d}$ at $50^{\circ} \mathrm{C}$ ). The average $\mathrm{DoH}$ of cement pastes were obtained from the Parrot and Killoh model $[32,34,35]$ for cases with $w / \mathrm{cm}$ of 0.36 and 0.50 as $80.4 \%$ (DoH of $\mathrm{C}_{3} \mathrm{~S}: 89.5 \%$; DoH of $\mathrm{C}_{2} \mathrm{~S}: 52.6 \%$ ) and $69.2 \%$ (DoH of $\mathrm{C}_{3} \mathrm{~S}$ : 80.6\%; DoH of $\mathrm{C}_{2} \mathrm{~S}: 36.4 \%$ ), respectively. For both systems the volumetric replacements were changed from 0 to $60 \%$, while the DoR of SCMs was varied from 0 to $100 \%$. In all cases $0 \%$ reactivity of SCM represents pure dilution.

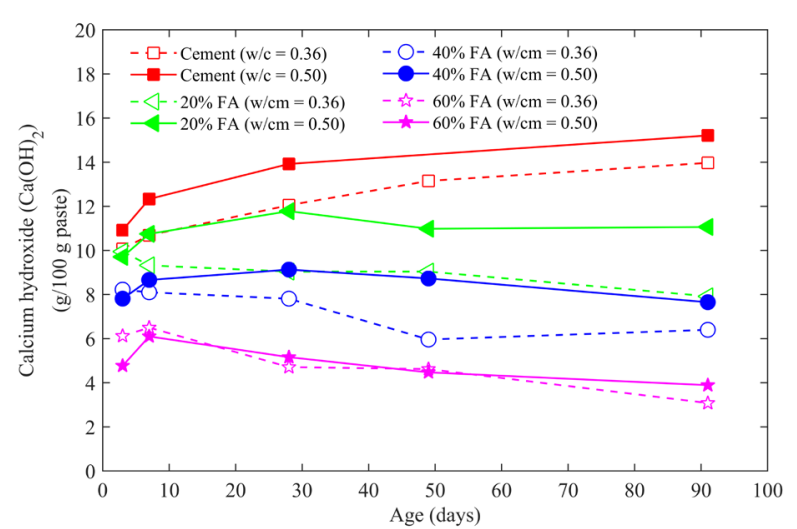

Figure 1. Variation in calcium hydroxide contents as a function of sample aging for plain cement pastes and with fly ash (FA). One data point (cement $\mathrm{w} / \mathrm{c}=0.50,49 \mathrm{~d}$ ) is not shown here as that particular sample was heavily carbonated and the data is therefore unreliable.

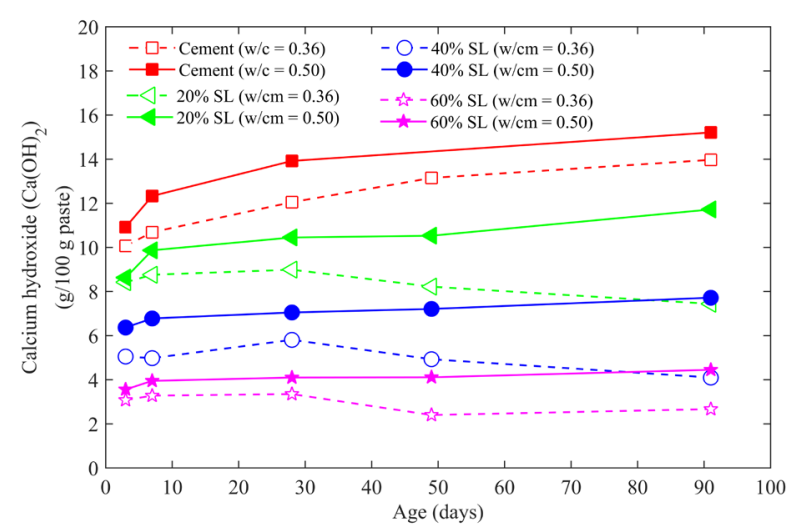

Figure 2. Variation in calcium hydroxide contents as a function of sample aging for plain cement pastes and with slag (SL). One data point (cement $w / c=0.50,49 d$ ) is not shown here as that particular sample was heavily carbonated and the data is therefore unreliable.

For the purpose of this analysis, it is assumed that the bulk SCM oxide contents are the same as the amorphous SCM oxide contents (i.e., the fly ash and slag contain no crystalline phases).

Fig. 3 and Fig. 4 show experimentally obtained $\mathrm{CH}$ contents at various SCM replacements. In addition, they show the obtained reductions in $\mathrm{CH}$ contents for $0,25,50$, and $100 \%$ DoR of the SCMs. For both fly ash and slag, the amount of $\mathrm{CH}$ in the pastes decreases with the level of SCM replacement and the DoR of SCMs. When comparing the figures, it is clear at a given DoR, reductions in $\mathrm{CH}$ contents are higher for fly ash than with the slag, likely because the fly ash is more pozzolanic than the slag. In general, the decrease in experimentally measured $\mathrm{CH}$ is more prominent for the lower $\mathrm{w} / \mathrm{cm}$ for both the slag and the fly ash (accounting for the fact that the lower $\mathrm{w} / \mathrm{cm}$ has a lower $\mathrm{CH}$ content to start with). This is especially true at lower SCM replacement levels. Specifically, reductions in $\mathrm{CH}$ contents are about $15 \%$ higher at a $20 \%$ fly ash replacement level but only about $3 \%$ higher at a $60 \%$ fly ash replacement level. These results imply a higher SCM DoR when the $\mathrm{w} / \mathrm{cm}$ is lower. However, it may not be valid to assume that systems with varying SCM replacements have the same cement $\mathrm{DoH}$. 
At early ages, there is acceleration of cement hydration with SCMs, implying that the cement DoH values are higher with SCMs than without them. The influence of SCMs on cement $\mathrm{DoH}$ at later ages is complex; alumina from SCM dissolution may slow down cement hydration [41], changes in $\mathrm{pH}$ due to the presence of SCMs may modify cement hydration [42], or the early age acceleration due to SCMs may persist at later ages.

Another possible reason for different cement DoH with SCMs is lack of enough water for continued hydration in some of these systems. Lack of water limiting hydration is taken into account here by considering the reactive (capillary) water, which was used as an input in thermodynamic analysis [38, 39]. For simplicity, in Fig. 3 and Fig. 4, this minimum water content was assumed to be zero, and the reactions (hydration and SCM reaction) are assumed to stop when reactive water was completely consumed. This is an idealized scenario; in fact, the reactions are significantly retarded before all water is consumed [43, 44]. This may occur at high DoH and DoR values. Fig. 3 and Fig. 4 show specific incidences of complete water consumption resulting in reaction stoppage at high DoH values. Preliminary experimental data also indicate that water consumption may be an issue as RH measurements carried out on $49 \mathrm{~d}$ samples indicated values below $80 \%$ for pastes with $\mathrm{w} / \mathrm{cm}$ 0.36 and SCMs; alite and belite essentially do not hydrate at such low RH values [43, 44].

From these results, it is clear that SCM replacements modify cement DoH. In order to better illustrate this, additional thermodynamic modeling was performed. Although several factors may affect DoH when SCMs are present, in this model, only the effect of reactive water availability was considered. For non-reactive fillers, one can reasonably assume that there is no water demand. As a result, since $\mathrm{w} / \mathrm{cm}$ is kept constant, higher water contents are available for the cements in systems with non-reactive fillers. This results in higher DoH values for the cement, which can be computed using thermodynamic modeling. As an example, the $\mathrm{DoH}$ increases from $69.2 \%$ to $83.5 \%$ for $60 \%$ replacement of a non-reactive filler. If we assume that SCMs behave the same way (higher water availability and higher DoH of cement), SCM DoR values can be recomputed. Fig. 5 illustrates a case with slag and $\mathrm{w} / \mathrm{cm}=0.36$. For simplicity, the DoH was assumed to be constant for all DoR levels. The points where reactions cease were obtained based on the idealized scenario where the reactive water is completely available. The implications of differing degrees of cement hydration on the perceived reactivity of the SCM are clearly illustrated in Fig. 5. This analysis may provide an explanation for the 'perceived' greater reactivity of the SCM at lower replacement levels as well as why the degree of reactivity appears to change with replacement levels.

Nevertheless, it should be pointed out that this is still an ongoing work that considers only $\mathrm{w} / \mathrm{cm}$ that changes with SCM replacement, assuming an initial DoH. In reality, SCMs may very well lower the cement DoH when the effect of SCM reactions on reactive water and the $\mathrm{DoH}$ are considered.

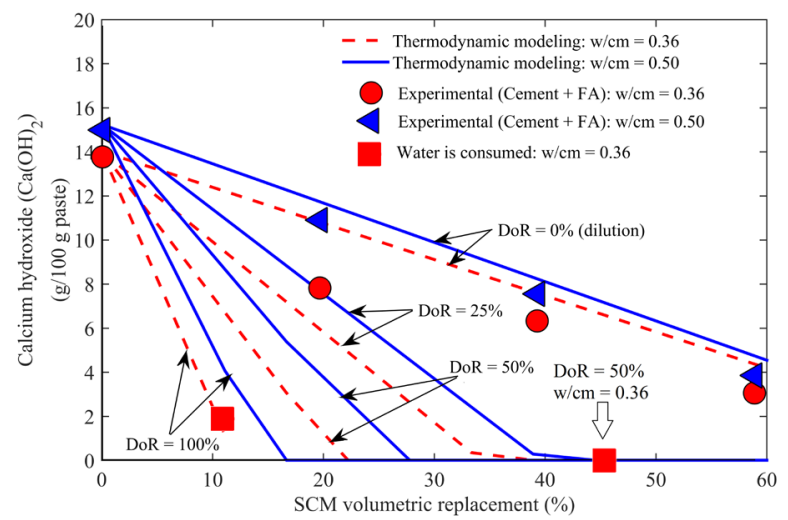

Figure 3. Calcium hydroxide contents and their reduction with fly ash replacement. Reductions in $\mathrm{CH}$ with fly ash DoR $0,25,50$, and $100 \%$ are shown.

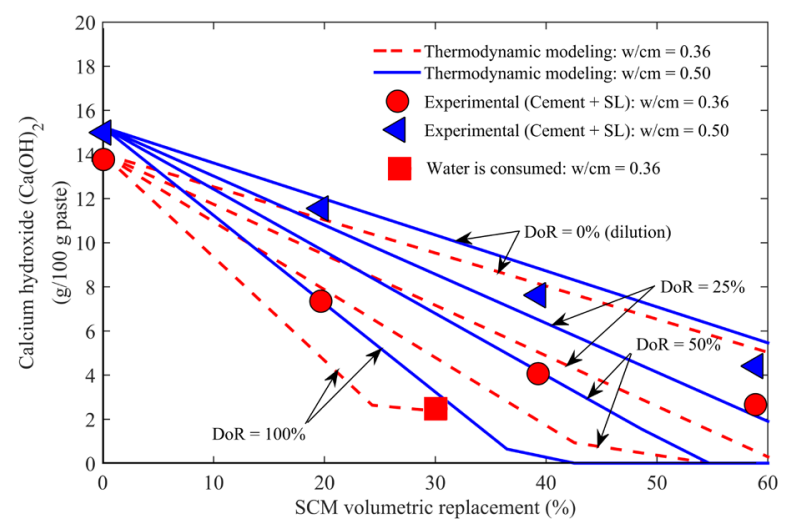

Figure 4. Calcium hydroxide contents and their reduction with slag replacement. Reductions in $\mathrm{CH}$ with fly ash DoR $0,25,50$, and $100 \%$ are shown.

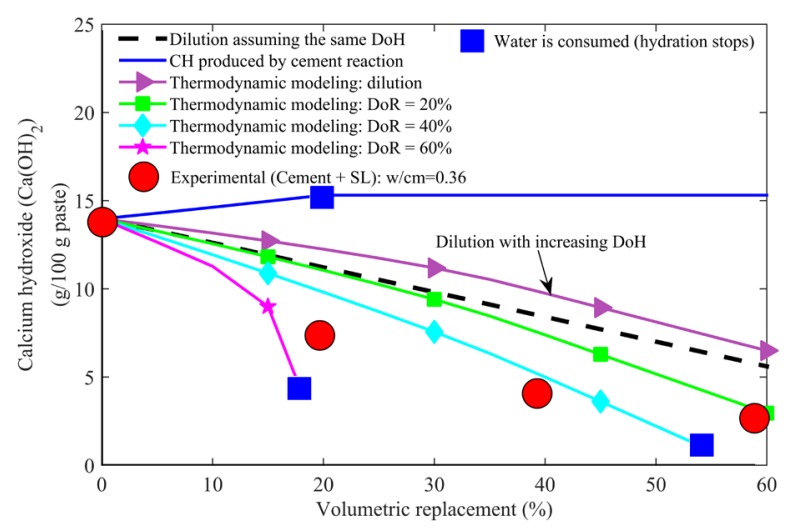

Figure 5. Calcium hydroxide contents and their reduction with SCM replacement with a variable cement DoH. Results are shown with slag and $\mathrm{w} / \mathrm{cm}=0.36$; DoH varies between $69.2 \%-83.5 \%$.

As the presence of SCM appears to influence the cement DoH [24, 45], additional methods such as calorimetry [46], backscatter scanning electron microscopy [24], or selective dissolution [47] are needed to accurately determine both SCM DoR and cement DoH.

\subsection{Calcium oxychloride (CAOXY) content}

Fig. 6 shows the measured CAOXY obtained from LT-DSC as a function of sample aging for plain cement pastes and with fly ash. Trends in CAOXY are similar to trends in $\mathrm{CH}$, and similar 
observations are made as in Fig. 1. In plain cements, CAOXY contents increase with sample aging; with SCMs, the values initially increase until $7 \mathrm{~d}$ and subsequently decrease. As the dosage of SCMs increases, CAOXY values decrease, due to a combination of the pozzolanic reaction and dilution. For example, a $40 \%$ replacement of SCM reduces $91 \mathrm{~d}$ equivalent CAOXY values by around $60 \%$, a $60 \%$ replacement reduces CAOXY values to almost zero, similar to observations made elsewhere [20-22]. CAOXY values with fly ash and slag (not shown) are broadly similar at the same replacement levels; these values, and also values for plain cements increase with $\mathrm{w} / \mathrm{cm}$.

Fig. 7 shows the relationship between CAOXY and $\mathrm{CH}$ contents for all tested samples. There is a strong correlation between the two: CAOXY values increase linearly with $\mathrm{CH}$ values. The slope obtained from linear regression is 2.73 , which is close to the value predicted from the reaction stoichiometry (2.47, the ratio of molecular weights of CAOXY, 549, and three times the molecular weight of $\mathrm{CH}, 74$ ) [24]. It should be noted that the CAOXY values decrease to zero at a positive value of $\mathrm{CH}$ (around 2), this is also similar to values noted elsewhere [24], possibly due to carbonation. However, it may be possible that a portion of the $\mathrm{CH}$ could be encapsulated by other hydrates, due to the pozzolanic reaction, resulting in it not being easily accessible to salt. These results indicate that is not necessary to reduce $\mathrm{CH}$ values to zero to eliminate CAOXY formation.

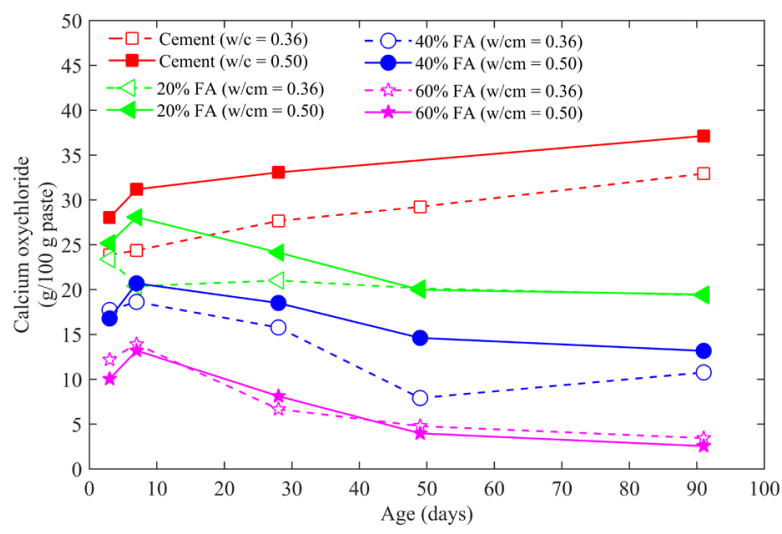

Figure 6. Variation in calcium oxychloride contents as a function of sample aging for plain cement pastes and with fly ash.

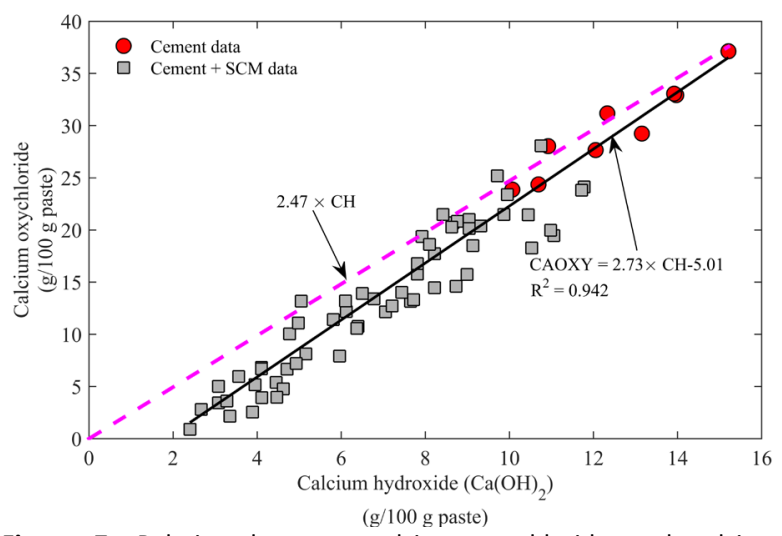

Figure 7. Relation between calcium oxychloride and calcium hydroxide contents for tested samples.

\subsection{Final thoughts on SCM reactivity and CAOXY reductions}

Most SCM DoR levels as noted from Fig. 3 and Fig. 4 are surprisingly low (less than $20 \%$ for $\mathrm{w} / \mathrm{cm} 0.50$ ), however, CAOXY values decrease significantly with increasing SCM replacement levels. This suggests that the primary benefit of the SCM in these cases is the effect of dilution. If this is true, the use of non-reactive fillers should have substantial benefits in reducing CAOXY formation due to reduction in $\mathrm{CH}$ contents through dilution. Prior work has shown that small limestone replacement levels (up to $12 \%$ ) did not show substantial reductions in CAOXY contents [20], but the effects of larger replacements levels, the method of limestone addition, and acceleration of cement hydration due to the presence of limestone $[37,40]$ still need be investigated further in order to fully understand the role of limestone replacement on CAOXY formation.

If the threshold level of CAOXY needed to cause damage in pavements can be determined, relationships that relate $\mathrm{CH}$ from TGA to CAOXY from LT-DSC could be useful to determine SCM replacement levels needed to prevent CAOXY damage in concrete pavements. It should be noted that a very rough estimate for the CAOXY needed to cause damage is suggested to be 5 to $10 \mathrm{~g}$ CAOXY/100 g paste which is equivalent to 2 to $4 \mathrm{~g} \mathrm{CH} / 100 \mathrm{~g}$ paste, assuming all the $\mathrm{CH}$ is reactive. This information and the plots presented in this letter are potentially very helpful in aiding mixture proportioning to prevent calcium oxychloride damage. It should be noted that these SCM limits refer only to the potential to reduce CAOXY formation and additional tests must be performed to study of the influence of these SCM replacement levels on other durability aspects such as scaling or reinforcing steel corrosion (if steel is present). It has been shown that the buffer capacity of $\mathrm{CH}$ plays an important role in the passivity and corrosion resistance of reinforcement in concrete, and high SCM replacement levels, even when they do not completely eliminate $\mathrm{CH}$ from the system, might decrease the buffer capacity of concrete, hence, leave reinforcement more vulnerable to chloride or carbonation induced corrosion [48].

\section{Summary}

The following items are the main points discussed in this letter:

- As the $w / c m$ increases the amount of calcium hydroxide (CH) produced by the cement hydration reaction increases. This implies that more CAOXY can be produced in higher $\mathrm{w} / \mathrm{cm}$ systems.

- In plain cements, the amount of $\mathrm{CH}$ and CAOXY increase with sample aging (degree of hydration).

- In systems where SCMs are used to replace cement, $\mathrm{CH}$ and CAOXY contents are reduced. This decrease is due to a combination of the pozzolanic reaction and dilution provided by the SCMs. 
- In systems where SCMs are used to replace cement, the values of $\mathrm{CH}$ and CAOXY initially increase (until $7 \mathrm{~d}$ ) due to hydration (and acceleration of cement hydration due to physical presence of SCMs); however at later ages the $\mathrm{CH}$ and CAOXY decrease due to dilution and pozzolanic reaction.

- It is proposed that the calculation of the degree of reaction (DoR) is complicated due to the assumption that the cement has hydrated to the same level for the plain system and the systems with SCMs. It is suggested that this assumption underestimates the extent of reaction of the SCM.

- CAOXY values increase linearly with $\mathrm{CH}$ values; the slope is close to the value predicted from fundamental chemical concepts. However, it should be noted that with SCMs, a small amount of $\mathrm{CH}$ may be present in the matrix which does not react to form CAOXY due to the potential for carbonation or encapsulation of $\mathrm{CH}$ with reaction products.

- Additional tests must be performed to study of the influence of high SCM replacement levels on other durability aspects such as scaling or reinforcing steel corrosion (if steel is present) due to the reduction in the $\mathrm{pH}$ buffer offered by the $\mathrm{CH}$.

\section{Acknowledgements}

The authors acknowledge funding from our sponsors Portland Cement Association (PCA) Foundation and National Ready Mixed Concrete Association (NRMCA) Foundation. The authors are grateful to Mitchell Keys, Naomi Salgado, and Hunter Carolan, undergraduate research assistants at Oregon State University, who performed some of the experiments reported here.

\section{References}

[1] X. Shi, L. Fay, C. Gallaway, K. Volkening, MM. Peterson, T. Pan, A. Creighton, C. Lawlor, S. Mumma, Y. Liu, TA. Nguyen, Evaluation of alternative anti-icing and deicing compounds using sodium chloride and magnesium chloride as baseline deicers - Phase I. Report CDOT2009-1, 2009.

[2] JJ. Valenza II, GW. Scherer, Mechanism for salt scaling. J Am Ceram Soc (2006) 89 (4): 1161-1179.

[3] JJ. Valenza II, GW. Scherer, A review of salt scaling: I. Phenomenology. Cem Concr Res (2007) 37 (7): 1007-1021.

[4] KAT. Vu, MG. Stewart, Structural reliability of concrete bridges including improved chloride-induced corrosion models. Struct Saf (2000) 22 (4): 313-333.

[5] X. Shi, L. Fay, Z. Yang, TA. Nguyen, Y. Liu, Corrosion of deicers to metals in transportation infrastructure: introduction and recent developments. Corros Rev (2009) 27 (1-2): 23-52.

[6] RK. Dhir, MAK. El-Mohr, TD. Dyer, Chloride binding in GGBS concrete. Cem Concr Res (1996) 26 (12): 1767-1773.

[7] UA. Birnin-Yauri, FP. Glasser, Friedel's salt, $\mathrm{Ca}_{2} \mathrm{Al}(\mathrm{OH})_{6}(\mathrm{Cl}, \mathrm{OH}) \cdot 2 \mathrm{H}_{2} \mathrm{O}$ : its solid solutions and their role in chloride binding. Cem Concr Res (1998) 28 (12): 1713-1723.

[8] S. Chatterji, Mechanism of the $\mathrm{CaCl}_{2}$ attack on portland cement concrete. Cem Concr Res (1978) 8 (4): 461-467.

[9] L. Berntsson, S. Chandra, Damage of concrete sleepers by calcium chloride. Cem Concr Res (1982) 12 (1): 87-92.
[10] X. Shi, M. Akin, T. Pan, L. Fay, Y. Liu, Z. Yang, Z, Deicer impacts on pavement materials: introduction and recent developments. Open Civ Eng J (2009) 3: 16-27.

[11] W. Jones, Y. Farnam, P. Imbrock, J. Spiro, C. Villani, M. Golias, J. Olek, WJ. Weiss, An overview of joint deterioration in concrete pavement: mechanisms, solution properties and sealers. Purdue University Report, 2013.

[12] P. Taylor, L. Sutter, WJ. Weiss, Investigation of deterioration of joints in concrete pavements, Report InTrans Project 09-361 (2012).

[13] Y. Farnam, S. Dick, A. Wiese, J. Davis, D. Bentz, WJ. Weiss, The influence of calcium chloride deicing salt on phase changes and damage development in cementitious materials. Cem Concr Comp (2015) 64: 1-15.

[14] Y. Farnam, A. Wiese, D. Bentz, J. Davis, WJ. Weiss, Damage development in cementitious materials exposed to magnesium chloride deicing salt. Constr Build Mater (2015) 93: 384-392.

[15] Y. Farnam, D. Bentz, A. Hampton, WJ. Weiss, Acoustic emission and low-temperature calorimetry study of freeze and thaw behavior in cementitious materials exposed to sodium chloride salt. Transport Res Rec (2014) 2441: 81-90.

[16] I. Galan, L. Perron, FP. Glasser, Impact of chloride-rich environments on cement paste mineralogy, Cem Concr Res (2015) 68: 174-183.

[17] National Research Council (USA), Highway deicing: comparing salt and calcium magnesium acetate, Transportation Research Board Special Report 235, 1991.

[18] X. Shi, Y. Liu, M. Mooney, M. Berry, B. Hubbard, L. Fay, AB. Leonard, Effect of chloride-based deicers on reinforced concrete structures, Report WA-RD 741.1, 2010.

[19] Y. Farnam, C. Villani, T. Washington, M. Spence, J. Jain, WJ. Weiss, Performance of carbonated calcium silicate based cement pastes and mortars exposed to $\mathrm{NaCl}$ and $\mathrm{MgCl}_{2}$ deicing salt. Constr Build Mater (2016) 111: 63-71.

[20] J. Monical, E. Unal, T. Barrett, Y. Farnam, WJ. Weiss, Reducing joint damage in concrete pavements: quantifying calcium oxychloride formation for concrete made using portland cement, portland limestone cement, supplementary cementitious materials, and sealers, Transport Res $\operatorname{Rec}(2016)$ in press.

[21] P. Suraneni, N. Salgado, H. Carolan, C. Li, V. Azad, B. Isgor, J. Ideker, J. Weiss, Mitigation of deicer damage in concrete pavements caused by calcium oxychloride formation - use of ground lightweight aggregates. Proc Int RILEM Conf on Materials, Systems and Structures in Civil Engineering, Denmark (2016) submitted.

[22] P. Suraneni, VJ. Azad, OB. Isgor, WJ. Weiss, Deicing salts and durability of concrete pavements and joints: Mitigating calcium oxychloride formation. Concr Int (2016) 38 (4): 48-54.

[23] RM. Ghantous, E. Unal, Y. Farnam, WJ. Weiss, The influence of carbonation on the formation of calcium oxychloride. Cem Concr Comp (2016) submitted.

[24] P. Suraneni, J. Monical, E. Unal, Y. Farnam, WJ. Weiss, Calcium oxychloride formation potential in cementitious pastes exposed to blends of deicing salt. ACI Mater J (2016) submitted.

[25] J. Monical, C. Villani, Y. Farnam, E. Unal, WJ. Weiss, Using lowtemperature differential scanning calorimetry to quantify calcium oxychloride formation for cementitious materials in the presence of $\mathrm{CaCl}_{2}, \mathrm{Adv}$ Civ Eng Mater (2016) in press.

[26] DA. Kulik, T. Wagner, SV. Dmytrieva, G. Kosakowski, FF. Hingerl, KV. Chudnenko, UR. Berner, GEM-Selektor Geochemical Modeling Package: Revised Algorithm and GEMS3K Numerical Kernel for Coupled Simulation Codes, Computat Geosci (2013) 17 (1): 1-24.

[27] BZ. Dilnesa, B. Lothenbach, G. Renaudin, A. Wichser, D. Kulik, Synthesis and characterization of hydrogarnet $\mathrm{Ca}_{3}\left(\mathrm{Al}_{x} \mathrm{Fe}_{1-x}\right)_{2}\left(\mathrm{SiO}_{4}\right)_{y}(\mathrm{OH})_{4(3-y)}, \mathrm{Cem}$ Concr Res (2014) 59: 96-111.

[28] B. Lothenbach B, L. Pelletier-Chaignat, F. Winnefeld, Stability in the system $\mathrm{CaO}-\mathrm{Al}_{2} \mathrm{O}_{3}-\mathrm{H}_{2} \mathrm{O}$. Cem Concr Res (2012) 42 (12): 1621-1634.

[29] DA. Kulik, Improving the structural consistency of C-S-H solid solution thermodynamic models. Cem Concr Res (2011) 41 (5): 477-495.

[30] G. Möschner, B. Lothenbach, F. Winnefeld, A. Ulrich, R. Figi, R. Kretzschmar, Solid solution between Al-ettringite and Fe-ettringite $\left(\mathrm{Ca}_{6}\left[\mathrm{Al}_{1-\mathrm{x}} \mathrm{Fe}_{\mathrm{x}}(\mathrm{OH})_{6}\right]_{2}\left(\mathrm{SO}_{4}\right)_{3} \cdot 26 \mathrm{H}_{2} \mathrm{O}\right)$. Cem Concr Res (2008) 39 (6): 482489.

[31] G. Möschner, B. Lothenbach, J. Rose, A. Ulrich, R. Figi, R. Kretzschmar, Solubility of Fe-ettringite $\left(\mathrm{Ca}_{6}\left[\mathrm{Fe}(\mathrm{OH})_{6}\right]_{2}\left(\mathrm{SO}_{4}\right)_{3} \cdot 26 \mathrm{H}_{2} \mathrm{O}\right)$. Geochim Cosmochim Acta (2008) 72 (1): 1-18.

[32] B. Lothenbach, T. Matschei, G. Möschner, FP. Glasser, Thermodynamic modelling of the effect of temperature on the hydration and porosity of Portland cement. Cem Concr Res (2008) 38 (1): 1-18. 
[33] T. Matschei, B. Lothenbach, FP. Glasser, Thermodynamic properties of Portland cement hydrates in the system $\mathrm{CaO}-\mathrm{Al}_{2} \mathrm{O}_{3}-\mathrm{SiO}_{2}-\mathrm{CaSO}_{4}{ }^{-}$ $\mathrm{CaCO}_{3}-\mathrm{H}_{2} \mathrm{O}$. Cem Concr Res (2007) 37 (10): 1379-1410.

[34] B. Lothenbach, F. Winnefeld, Thermodynamic modelling of the hydration of Portland cement. Cem Concr Res (2006) 36 (2): 209226.

[35] U. Parrot, DC. Killoh, Prediction of cement hydration. Proc Br Ceram Soc (1984) 35: 41-53.

[36] X. Feng, EJ. Garboczi, DP. Bentz, PE. Stutzman, Estimation of the degree of hydration of blended cement pastes by a scanning electron microscope point-counting procedure. Cem Concr Res (2004) 34 (10): 1787-1793.

[37] DP. Bentz, T. Sato, I. de la Varga, WJ. Weiss, Fine limestone additions to regulate setting in high volume fly ash mixtures. Cem Concr Comp (2012) 34 (1): 11-17.

[38] TC. Powers; TL. Brownyard, Studies of the physical properties of hardened Portland cement paste. Proc J Am Conc I (1947) 43.

[39] VJ. Azad, P. Suraneni, OB. Isgor, WJ. Weiss, Combining Powers' model with thermodynamic modeling to better understand hydrating cement pastes. Adv Civ Eng Mater (2016) to be submitted.

[40] E. Berodier, K. Scrivener, K, Understanding the filler effect on the nucleation and growth of C-S-H. J Am Ceram Soc (2014) 97 (12): 3764-3773.
[41] P. Suraneni, RJ. Flatt, Use of micro-reactors to obtain new insights into the factors influencing tricalcium silicate dissolution. Cem Concr Res (2015) 78B: 208-215.

[42] A. Kumar, G. Sant, C. Patapy, C. Gianocca, KL. Scrivener, The influence of sodium and potassium hydroxide on alite hydration: Experiments and simulations. Cem Concr Res (2012) 42 (11): 1513-1523.

[43] OM. Jensen, PF. Hansen, EE. Lachowski, FP. Glasser, Clinker mineral hydration at reduced relative humidities. Cem Concr Res (1999) 29 (9): 1505-1512.

[44] RJ. Flatt, GW. Scherer, JW. Bullard, Why alite stops hydrating below $80 \%$ relative humidity. Cem Concr Res (2011) 41 (9): 987-992.

[45] B. Lothenbach, K. Scrivener, RD. Hooton, Supplementary cementitious materials. Cem Concr Res (2011) 41 (12): 1244-1256.

[46] V. Kocaba, E. Gallucci, KL. Scrivener, Methods for determination of degree of reaction of slag in blended cement pastes. Cem Concr Res (2012) 42 (3): 511-525.

[47] L. Lam, YL. Wong, CS. Poon, Degree of hydration and gel/space ratio of high-volume fly ash/cement systems. Cem Concr Res (2000) 30 (5): 747-756.

[48] VJ. Azad, OB. Isgor, A thermodynamic perspective on chloride limits of concrete produced with SCMs, ACI Special Publication 308 (2016) in press. 